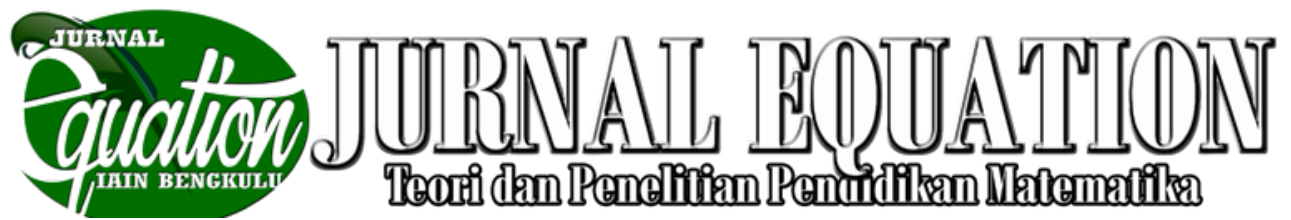

Volume 1 Nomor 2, September 2018, ISSN 2599-3291 (Cetak), ISSN 2614-3933 (Online)

\title{
Penggunaan Sempoa Untuk Meningkatkan Mental Aritmetika Siswa SD pada Pembelajaran Kabataku
}

\author{
Roples Dianto1), Devi Setiowati²), Lailatul Mukaromah ${ }^{3)}$ \\ Fakultas Tarbiyah dan Tadris, IAIN Bengkulu \\ roplesdianto@gmail.com
}

\begin{abstract}
ABSTRAK
Tujuan penulisan karya tulis ini adalah mengajak pembaca untuk mengetahui tekhnik berhitung berdasarkan teori matematika dengan menggunakan sempoa sebagai alat bantu yang terdiri dari manik-manik yang dapat digerak-gerakkan keatas atau kebawah. Begitu pentingnya sempoa untuk merangsang daya fikir otak anak.Maka dari itu penulis mengajak pembaca untuk menggunakan sempoa sebagai alat bantu pembelajaran Matematika.
\end{abstract}

Kata Kunci: Sempoa, Mental Aritmatika

\section{PENDAHULUAN}

Matematika merupakan salah satu pembelajaran yang kurang disenangi dan sangat dibenci oleh sebagian murid, siswa dan bahkan mahasiswa. Matematika itu sendiri menjadi momok yang paling menakutkan oleh sebagian peserta didik baik pembelajarannya maupun tenaga pengajarnya.

Salah satu cara memajukan kinerja matematika adalah dengan menggunakan Sempoa. Metode Sempoa adalah teknik berhitung berdasarkan teori matematika dengan menggunakan sempoa sebagai alat bantu yang terdiri dari manik-manik yang dapat digerak-gerakan keatas atau kebawah untuk merangsang daya fikir otak anak. Berhitung dengan menggunakan sempoa sebenarnya sudah ditemukan sejak dahulu kala namun masih memiliki keuntungan yang

Roples

Penggunaan Sempoa... sama meskipun kita telah berada di zaman komputer dan informasi.

Adapun mental aritmatika adalah proses berpikir mengimajinasikan sempoa didalam benak anak, sehingga tidak heran apabila banyak siswa-siswi yang telah mempelajari sempoa dan mental aritmatika dapat berhitung sangat cepat, dibandingkan dengan cara berhitung yang konfesional. Makna dari "SEMPOA" adalah singkatan dari Sistem Edukasi Mengoptimalkan Potensi Otak Anak, maksudnya bahwa dengan belajar sempoa, maka kemampuan berfikir siswa dapat terus di tingkatkan.

Tujuan dari penulisan karya ilmiah ini yaitu untuk mengetahui cara alat bantu sempoa untuk meningkatkan mental aritmatika siswa SD. 


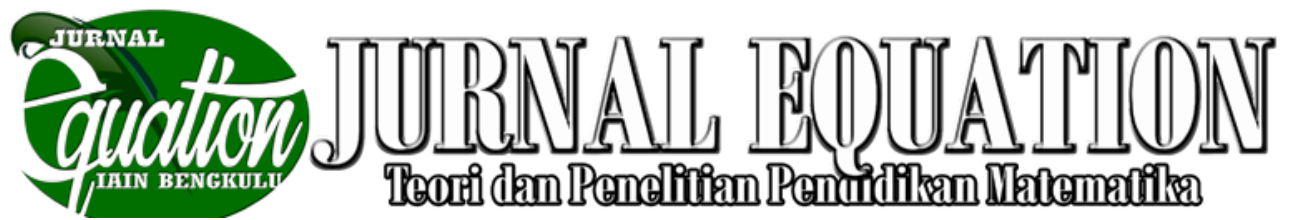

Volume 1 Nomor 2, September 2018, ISSN 2599-3291 (Cetak), ISSN 2614-3933 (Online)

\section{Pengertian Sempoa}

Sempoa adalah singkatan dari Sistem Edukasi Mengoptimalkan Potensi Otak Anak, maksudnya bahwa dengan belajar sempoa, maka kemampuan berfikir siswa dapat terus ditingkatkan.

Metode sempoa adalah tekhnik berhitung berdasarkan teori matematika dengan menggunakan sempoa sebagai alaat bantu yang terdiri dari manik-manik yang dapat digerak-gerakan keatas atau kebawah untuk merangsang daya fikir otak anak.

\section{Sejarah Sempoa}

Sempoa dikenal sebagai sebuah alat hitung aritmetika kuno yang telah digunakan sejak dulu.Konon, perkembangan alat hitung ini bermula di Babilonia pada rentang tahun 2700 SM hingga 2300 SM.

Menurut penelitian para ahli sejarah, sempoa milik bangsa Babilonia tersebut bisa digunakan untuk melakukan operasi pertambahan dan pengurangan.Meski, metode yang dilakukan lebih kompleks dibandingkan sempoa yang ada saat ini.

Selanjutnya, ada pula sempoa dari bangsa Yunani yang diketahui berasal dari tahun 300 SM, disebut dengan nama Salamis Tablet. Sempoa dari Yunani ini pun jadi papan bantu hitung tertua di dunia yang pernah ditemukan hingga saat ini, dengan dimensi $149 \times 75 \times 4,5 \mathrm{~cm}$.

Roples

Penggunaan Sempoa...
Sementara itu, versi sempoa pertama yang dimiliki oleh bangsa Tiongkok disebut dengan nama suanpan, diketahui berasal dari abad 2 SM. Suanpan dari Tiongkok ini bisa digunakan untuk berbagai jenis operasi aritmetika. Mulai dari penjumlahan, pengurangan, pengalian, pembagian, akar kuadrat, ataupun akar pangkat tiga.

Berikutnya, ada pula sempoa dari Jepang yang tercatat muncul pada abad ke 14 M. Sempoa Jepang ini berasa dari daratan Cina, dan disebut dengan nama soroban. Di waktu yang sama, sempoa Cina juga dibawa ke negeri Korea dan disebut dengan nama jupan atau supan atau jusan.

Tidak ketinggalan, bangsa-bangsa asli di Benua Amerika juga mengadopsi penggunaan sempoa. Menurut catatan sejarah, terdapat dua jenis alat bantu hitung mirip sempoa yang digunakan oleh bangsa Inca di Amerika, yakni quipu dan yupana.

Ada pula sempoa dari bangsa Rusia yang disebut dengan nama schoty. Penggunaan sempoa schoty menyebar luas pada saat Uni Soviet masih berdiri.Bahkan, schoty diperkenalkan oleh bangsa Rusia ke beberapa negera Eropa lainnya termasuk di antaranya adalah Prancis.

\section{Kegunaan Sempoa}

Sempoa digunakan untuk membantu perhitungan aritmetika, Mulai dari operasi pengurangan, penjumlahan, pembagian, 


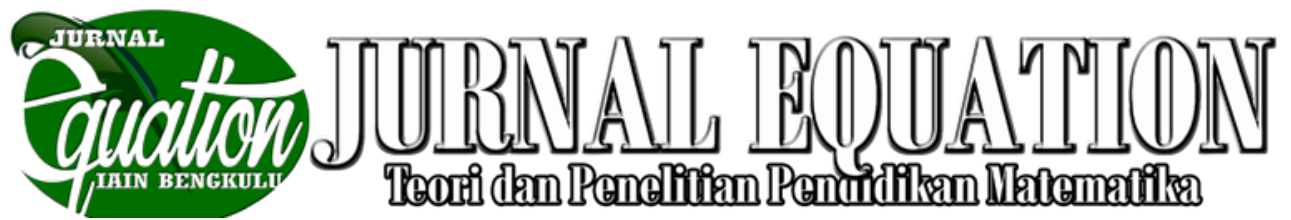

Volume 1 Nomor 2, September 2018, ISSN 2599-3291 (Cetak), ISSN 2614-3933 (Online)

perkalian, hingga operasi akar kuadrat.Tidak heran, kalau metode pembelajaran matematika menggunakan sempoa banyak diajarkan kepada anak-anak. Praktis dan relatif lebih mudah dibandingkan cara konvensional.

Selain itu, sempoa juga memberi manfaat tinggi untuk para penderita tunanetra.Karena tidak memiliki penglihatan seperti orang normal, sempoa dapat membantu para tunanetra untuk menghitung dengan memanfaatkan indera peraba.Belajar operasi aritmetika menggunakan sempoa, para tunanetra bisa memiliki kemampuan matematika yang tidak kalah dengan orang normal.

\section{Pengertian Mental Aritmatika}

Mental aritmatika terdiri dari dua kata yaitu mental dan aritmatika.Mental merupakankata sifat yang berasal dari bahasa inggris yang berarti sesuatu yang berkaitan dengan jiwa, batin atau rohani.Kemudian aritmatika berasal dari bahasa yunani arithmatike, yang berasal dari dua kata yaitu aritmos yang berarti angka/bilangan dan techne yang berarti ilmu pengetahuan.Jadi mental aritmatika adalah ilmu hitung diluar kepala. Maksudnya suatu ilmu yang mempelajari cara berhitung(tambah, kurang, kali, dan bagi) melalui alat yang dinamakan sempoa, kemudian dalam perkembangan selanjutnya operasi hitungan cukup dibayangkan secara mental didalam otak seperti menggerakkan sempoa.

\section{Pentingnya Mempelajari Mental Aritmatika}

Sempoa amat memudahkan kita dalam melakukan proses berhitung. Kecepatan kita dalam menghitung angka meningkat dengan pesat dan jawaban yang didapatpun menjadi lebih akurat.Saya sebagai siswa yang pernah mempelajari teknik berhitung dengan sempoa sangat merasakan manfaatnya mulai sejak bangku SD hingga kini duduk di SMA.

Saya mulai mempelajari sempoa sejak kelas satu SD. Hasilnya tidak sia-sia.Saya mampu berhitung jauh lebih cepat dari temanteman sekelas dan ini membuahkan keuntungan besar bagi saya, terutama menjelang tes matematika. Tidak perlu kertas coret-coretan untuk menulis perkalian ke bawah saya cukup membayangkannya selama beberapa detik saja, dan langsung menemukan jawabannya. Anda tahu, sebenarnya yang paling menghambat dalam tes matematika (selain lupa rumus) adalah proses menghitungnya plus keraguan menjelang proses tersebut, sehingga terkadang harus mengulangi kembali. Dan keunggulan dalam menghemat waktu dapat digunakan untuk memeriksa kembali jawaban-jawaban seingga kemungkinan salah berkurang.Dalam setiap tes, kesempatan untuk memeriksa jawaban mempunyai peluang untuk membedakan antara angka 


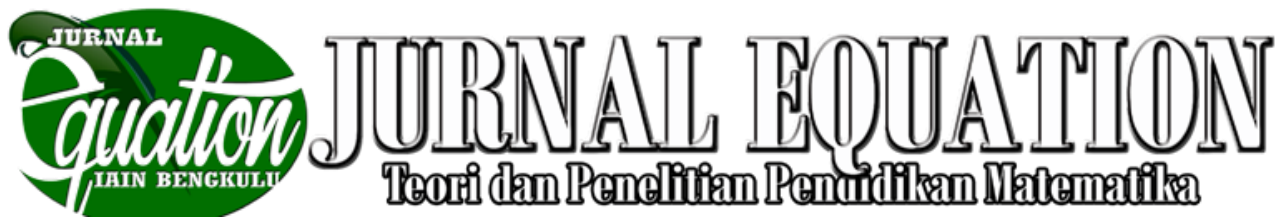

Volume 1 Nomor 2, September 2018, ISSN 2599-3291 (Cetak), ISSN 2614-3933 (Online)

merah dan nilai aman. Manfaat-manfaat lain dari mental aritmatika adalah sebagai berikut:

a. Mengoptimalkan funsi otak. Mental aritmatika terbukti sangat berguna dalam mengoptimalkan fungsi-fungsi otak (otak kanan khususnya) yang meliputi daya analisa, ingatan, logika, visi, kemandirian, ketekunan, penemuan dan penerapan. Dengan memahami disiplin dasar eksakta ini, manusia diharapkan dapat menguasai dan menggunakan secara optimal seluruh potensi dan kreativitas yang ada dalam menyerap ilmu - ilmu yang tentunya akan bermanfaat dalam kehidupannya seharihari.

b. Melatih daya imajinasi dan kreativitas, logika, sistematika berfikir, daya konsenterasi dan daya ingat. Ini dicapai dengan melatih otak kiri dan kanan menjadi lebih aktif melalui mental aritmatika.

c. Meningkatkan kecepatan, ketepatan dan ketelitian dalam berfikir

d. Menjadi lebih sensitif terhadap aransemen spatial akibat pengaruh dari membayangkan sempoa dalam otak kita.

e. Untuk anak-anak yang suka lalai menghafal rumus perkalian, mental aritmatika sangat membantu. f. Menumbuhkan rasa percaya diri dan sikap mental positif, terutama dalam menghadapi soal-soal matematika.

Semua manfaat diatas akan memupuk anak untuk menghadapi persaingan di era milenium ini yang banyak mengandalkan kecerdasan otak.

Buktinya, Jepang di masa gelapnya setelah perang dunia ke-2 mampu bangkit kembali dan sekarang telah menjadi negara yang makmur dengan industri berbasis teknologi terdepan. Kesuksesan yang sama juga dicapai oleh China dan Korea Selatan karena seluruh teknologi manusia dibangun dari dasar-dasar matematika. Poin terpenting disini adalah bahwa orang yang menguasai teknik berhitung cepat dengan otak aktifnya akan jauh lebih terbuka terhdapa ide-ide kreatif baru. Tokoh-tokoh besar dunia pun banyak yang menggemari permainan berhitung cepat.

\section{METODOLOGI PENULISAN}

Jenis penelitian yang digunakan dalam penulisan karya ilmiah ini adalah metode secara langsung atau tinjauan pustaka, yakni dengan cara mengkaji berbagai referensi yang berhubungan dengan sempoa dan pembelajaran matematika tentang perkalian, pembagian, penjumlahan, dan pengurangan.

Pengumpulan data yang digunakan dalam penulisan karya tulis ini yaitu melalui studi literatur (literature research). Data yang 


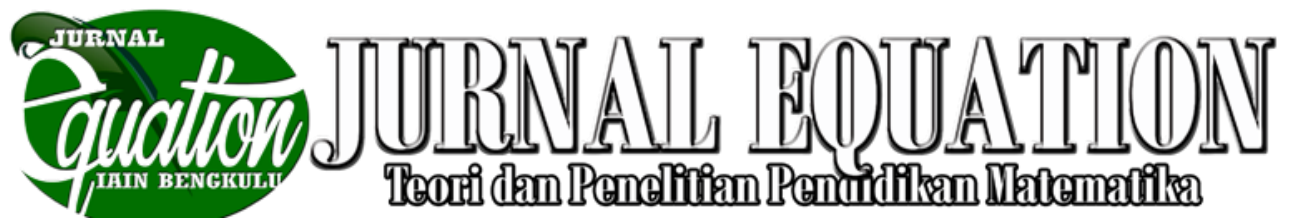

Volume 1 Nomor 2, September 2018, ISSN 2599-3291 (Cetak), ISSN 2614-3933 (Online)

dikumpulkan adalah data yang berkaitan dengan Sempoa dan pembelajaran matematika tentang perkalian, pembagian, penjumlahan, dan pengurangan. Data ini diperoleh dari internet yaitu website, bukubuku, bacaan ilmiah dan berbagai sumber yang mendukung dan valid.

\section{HASIL DAN PEMBAHASAN}

Cara Penggunaan Sempoa Untuk Meningkatkan Mental Aritmatika Siswa SD

Sempoa amat memudahkan kita dalam melakukan proses berhitung. Kecepatan kita dalam menghitung angka meningkat dengan pesat dan jawaban yang didapatpun menjadi lebih akurat.Saya sebagai siswa yang pernah mempelajari teknik berhitung dengan sempoa sangat merasakan manfaatnya mulai sejak bangku SD hingga kini duduk di SMA.

Saya mulai mempelajari sempoa sejak kelas satu SD. Hasilnya tidak sia-sia.Saya mampu berhitung jauh lebih cepat dari temanteman sekelas dan ini membuahkan keuntungan besar bagi saya, terutama menjelang tes matematika.Tidak perlu kertas coret-coretan untuk menulis perkalian ke bawahsaya cukup membayangkannya selama beberapa detik saja, dan langsung menemukan jawabannya. Anda tahu, sebenarnya yang paling menghambat dalam tes matematika (selain lupa rumus) adalah proses menghitungnya plus keraguan menjelang proses tersebut, sehingga terkadang harus mengulangi kembali. Dan keunggulan dalam menghemat waktu dapat digunakan untuk memeriksa kembali jawaban-jawaban seingga kemungkinan salah berkurang.Dalam setiap tes, kesempatan untuk memeriksa jawaban mempunyai peluang untuk membedakan antara angka merah dan nilai aman.

Cara menggunakan Sempoa Untuk meningkatkan Mental Aritmatika :

1. Posisikan sempoa dengan benar. Sebuah sempoa standar terdiri dari dua baris manik-manik yang tersusun berdasarkan jumlah variabel kolom. Setiap kolom di baris atas memiliki satu atau dua manik-manik setiap barisnya, sedangkan setiap kolom di baris bawah memiliki empat manikmanik. Saat kamu mulai, semua manikmanik yang ada di baris atas harus berada di atas dan yang ada di baris bawah harus berada di bawah. Manikmanik di baris atas mewakili nilai angka 5 sedangkan setiap manik-manik di baris bawah mewakili nilai angka 1.

Saat kamu sudah semakin terbiasa dengan penggunaan sempoa, kamu bisa memberikan nilai berbeda untuk setiap manik-manik di baris bawah untuk melakukan perhitungan yang lebih rumit. Akan tetapi, manik-manik di baris atas harus bernilai $5 x$ dari nilai setiap manik- 


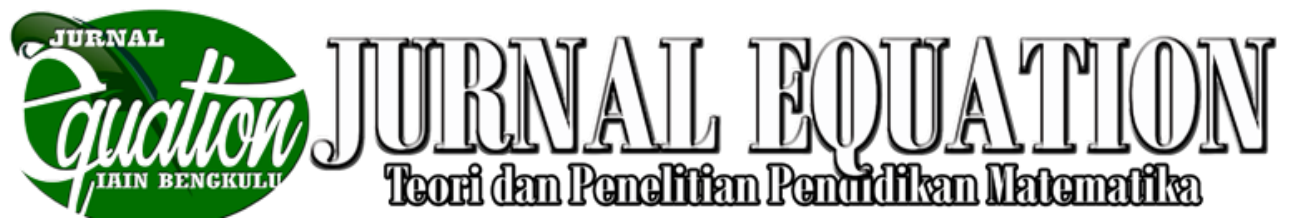

Volume 1 Nomor 2, September 2018, ISSN 2599-3291 (Cetak), ISSN 2614-3933 (Online)

manik di baris bawah agar sempoa bisa digunakan.

2. Berikan setiap kolom nilai tempat. Pada kalkulator modern, setiap kolom manikmanik mewakili nilai "tempat". Jadi, kolom terjauh di kanan adalah nilai tempat "satu" (1-9), kedua terjauh adalah nilai tempat "puluhan" (10-99), ketiga terjauh adalah nilai tempat "ratusan" (100-999), dan seterus bergantung pada perhitunganmu, kamu juga bisa memberikan tempat desimal yang harus diperhatikan. Jika kamu ingin memasukkan angka 12.345,67, angka 7 berada di kolom pertama, 6 di kolom kedua, 5 di kolom ketiga, dan seterusnya. Saat melakukan perhitungan ini, kamu hanya harus mengingat letak desimalnya, tandai dengan pensil pada sempoanya, atau kamu bisa melewati satu baris dan membiarkannya "kosong" untuk membantumu.

3. Mulailah menghitung. Untuk menghitung sebuah digit, "naikkan" sebuah manikmanik. "Satu" diwakili dengan menaikkan satu manik-manik dari baris bawah pada kolom terjauh di kanan, "dua" dengan menaikkan dua, dan seterusnya.

4. Lakukan "perpindahan dari 4 ke 5". Karena hanya ada empat manikmanik di baris bawah, kamu bisa "menurunkan" manik-manik di baris atas dan "menurunkan" keempat manik-manik di baris bawah, untuk memindahkan angka dari "empat" ke "lima". Sempoa saat ini menunjukkan angka "lima". Untuk menghitung "enam", "naikkan" satu manik-manik di baris bawah, sehingga manik-manik di baris atas turun (mewakili nilai 5) dan satu manik-manik di baris bawah naik.

Proses ini berlaku sama untuk setiap bagian sempoa. Pindahkan angka "sembilan", dengan semua manik-manik di baris bawah "naik" dan manik-manik di baris atas "turun", ke angka "sepuluh", dengan "menaikkan" satu manik-manik dinilai tempat puluhan.

Jadi, untuk mengilustrasikan: 12345 akan diwakilkan dengan manik-manik di baris atas "turun" di nilai tempat satu, empat manikmanik di baris bawah "naik" di nilai tempat puluhan, tiga manik-manik di baris bawah "naik" di nilai tempat ratusan, dua manikmanik di baris bawah "naik" di nilai tempat ribuan, dan satu manik-manik di baris bawah "naik" di nilai tempat puluh ribuan.

Sangat mudah untuk lupa "menurunkan" manik-manik di baris bawah saat berpindah tempat, membuat sempoanya menunjukkan angka yang salah. Memang mudah untuk mengingatnya saat kamu menghitung, tetapi saat kamu menyelesaikan perhitungan yang rumit, akan bertambah sulit. 


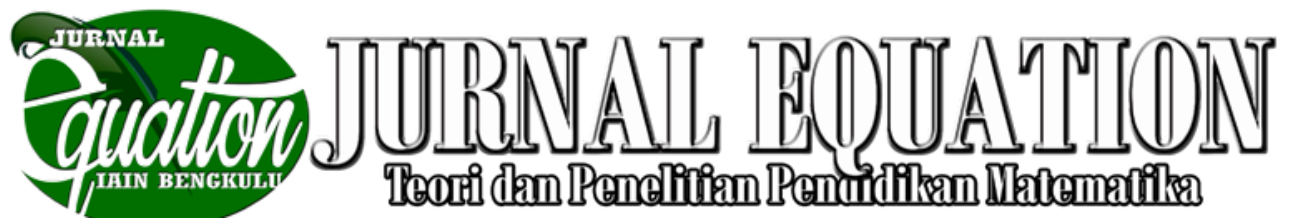

Volume 1 Nomor 2, September 2018, ISSN 2599-3291 (Cetak), ISSN 2614-3933 (Online)

Kelebihan Sempoa:Sempoa amat memudahkan kita dalam melakukan proses berhitung. Kecepatan kita dalam menghitung angka meningkat dengan pesat dan jawaban yang didapatpun menjadi lebih akurat.Saya sebagai siswa yang pernah mempelajari teknik berhitung dengan sempoa sangat merasakan manfaatnya mulai sejak bangku SD hingga kini duduk di SMA.

Saya mulai mempelajari sempoa sejak kelas satu SD. Hasilnya tidak sia-sia.Saya mampu berhitung jauh lebih cepat dari temanteman sekelas dan ini membuahkan keuntungan besar bagi saya, terutama menjelang tes matematika. Tidak perlu kertas coret-coretan untuk menulis perkalian kebawahsaya cukup membayangkannya selama beberapa detik saja, dan langsung menemukan jawabannya. Anda tahu, sebenarnya yang paling menghambat dalam tes matematika (selain lupa rumus) adalah proses menghitungnya plus keraguan menjelang proses tersebut, sehingga terkadang harus mengulangi kembali. Dan keunggulan dalam menghemat waktu dapat digunakan untuk memeriksa kembali jawaban-jawaban seingga kemungkinan salah berkurang.Dalam setiap tes, kesempatan untuk memeriksa jawaban mempunyai peluang untuk membedakan antara angka merah dan nilai aman.
Kekurangan Sempoa: Hal-hal positif dari sempoa membuat banyak orang merasa perlu untuk belajar sempoa. Kita pun tak heran melihat seorang anak TK, misalnya, mampu berhitung dengan amat cepat melebihi alat hitung mesin, seperti kalkulator, meskipun hanya aritmatika dasar. "Tidak ada gading yang tak retak," bunyi pepatah.Sempoa juga demikian.Hal-hal positif yang luar biasa tak melulu menjadi kekayaan sempoa.Ada juga kelemahannya.Sempoa hanya unggul dalam perhitungan dasar, namun sulit dalam operasi yang rumit.

Perlu juga diketahui, sempoa hanya salah satu cara berhitung. Sempoa bukan matematika, dan matematika bukan sempoa.Keduanya tidak boleh disamakan. Matematika memiliki cara kerjanya sendiri. Seseorang yang menguasai sempoa belum tentu ahli matematika.

Memberikan sarana pembelajaran matematika menggunakan sempoa bukanlah hal yang asing di Indonesia. Banyak orangtua yang dengan sengaja menyediakan alat hitung tradisional Tiongkok ini sebagai alat bantu belajar operasi matematika. Hasil pembelajaran dengan sempoa pun terlihat jelas, kemampuan berhitung anak-anaknya jauh lebih baik. 


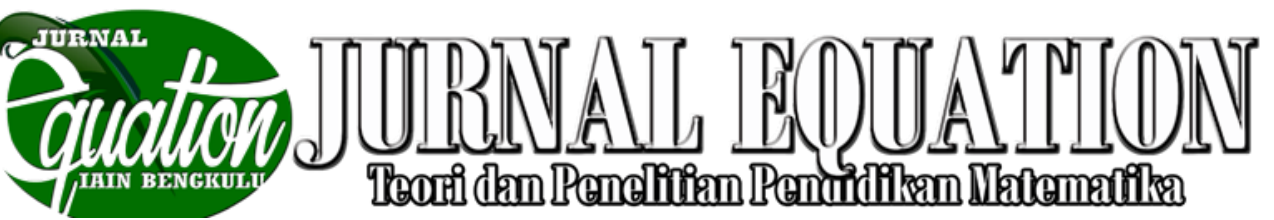

Volume 1 Nomor 2, September 2018, ISSN 2599-3291 (Cetak), ISSN 2614-3933 (Online)

\section{PENUTUP}

\section{Kesimpulan}

Dari penjelasan di atas dapat disimpulkan bahwa sempoa mampu membantu kita dalam mengerjakan tugas matematika. Sempo juga sangat cocok digunakan oleh para siswa tingkat SD karena penggunaannya yang mudah. Sempoa amat memudahkan kita dalam melakukan proses berhitung. Kecepatan kita dalam menghitung angka meningkat dengan pesat dan jawaban yang didapatpun menjadi lebih akurat. Maka dari itu dapat diperjelas bahwa sempoa memang banyak pengaruh dan manfaatnya untuk meningkatkan mental aritmatika khususnya dikalangan SD.

\section{Saran}

Berdasarkan penjelasan di atas, maka kami merekomendasikan kepada para guruatau para pengajar lainnya untuk menggunakan alat bantu sempoa di kalangan siswa SD saat mengajarkan matematika terutama pada materi perkalian, pembagian, penjumlahan, dan pengurangan. Karena dengan menggunakan alat bantu sempoa maka siswa akan merasa tertarik untuk mengikuti kegiatan pembelajaran dan juga dapat meningkatkan mental aritmatika siswa.

\section{DAFTAR PUSTAKA}

Bachtiar,

Mahdi. 2014.Mental Aritmatika.http://searchengines. Diakses pada 11 febuari 2019.

Mbachtiar. 2014. Konsep dasar Mental Aritmatika.

http://bglconline.com.Diakses pada 11 febuari 2019

Mahmudi, Ali. 2017.Manfaat Sempoa untik Siswa

$S D$.

UNY. 